


\section{U.S. Department of the Interior \\ KEN SALAZAR, Secretary \\ U.S. Geological Survey \\ Marcia K. McNutt, Director}

U.S. Geological Survey, Reston, Virginia: 2011

This and other USGS information products are available at http://store.usgs.gov/

U.S. Geological Survey

Box 25286, Denver Federal Center

Denver, CO 80225

To learn about the USGS and its information products visit http://www.usgs.gov/

1-888-ASK-USGS

Any use of trade, product, or firm names is for descriptive purposes only and does not imply endorsement by the U.S. Government.

Although this report is in the public domain, permission must be secured from the individual copyright owners to reproduce any copyrighted materials contained within this report.

Suggested citation:

Fundamental Science Practices Advisory Committee, 2011, U.S. Geological Survey Fundamental Science Practices: U.S. Geological Survey Circular 1367, 8 p. 


\section{Contents}

Background. 1

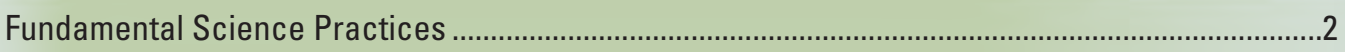

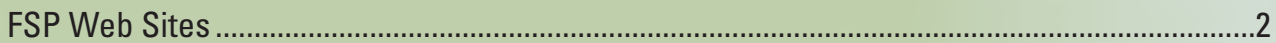

Roles and Responsibilities .................................................................................................

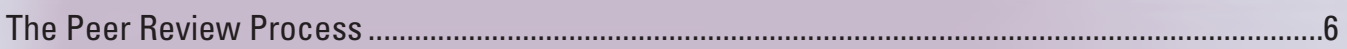

USGS Peer Review Requirements ....................................................................................

Federal Peer Review Requirements .................................................................................

The Bureau Approval Process.....................................................................................................

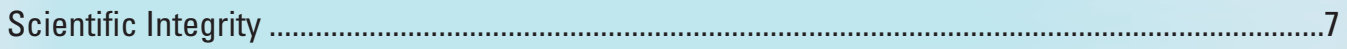

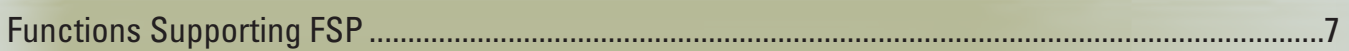

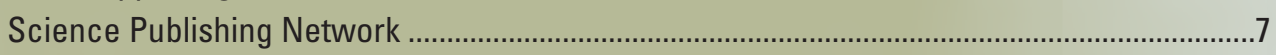

Information Product Data System ...............................................................................

\section{Fundamental Science Practices Advisory Committee}

Cindi Barton, Science Center Director, Tacoma, Washington

Terry D'Erchia, Assistant Director, Core Science Informatics, Denver, Colorado (past member)

Keith Kirk, Bureau Approving Official, Santa Cruz, California

Lenny Konikow, Publishing Scientist, Reston, Virginia

Rama Kotra, Program Coordinator, Reston, Virginia

Mike Jawson, Science Center Director, La Crosse, Wisconsin

Bill Orem, Publishing Scientist, Reston, Virginia

Phil Redman, IPDS Administrator, Madison, Wisconsin

Carolyn Reid, Policy Coordinator, Reston, Virginia

Jonathan Stock, Publishing Scientist, Menlo Park, California

Tom Suchanek, Publishing Scientist, Sacramento, California

Ione Taylor, Associate Director, Reston, Virginia

Charles Van Riper III, Publishing Scientist, Tucson, Arizona

Randy Updike, Area Executive, Denver, Colorado
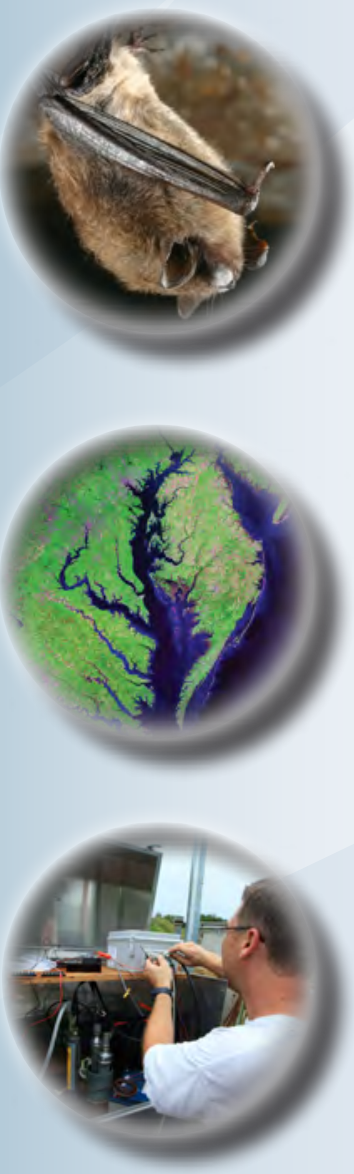
$y+1,0=$ 12. 175

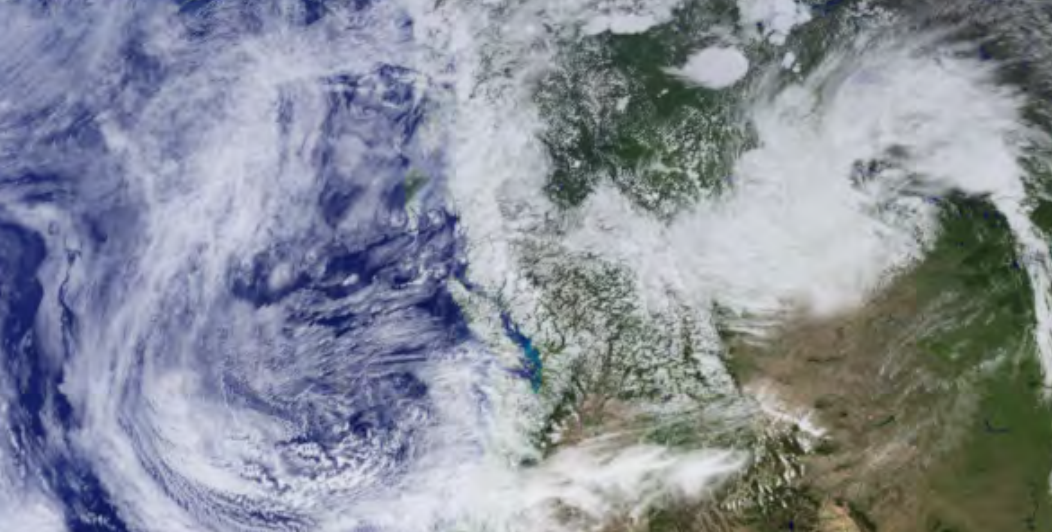

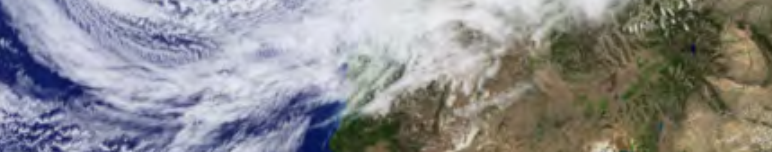

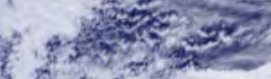 \\ $\rightarrow$ \\ 2. 20 \\ (1)

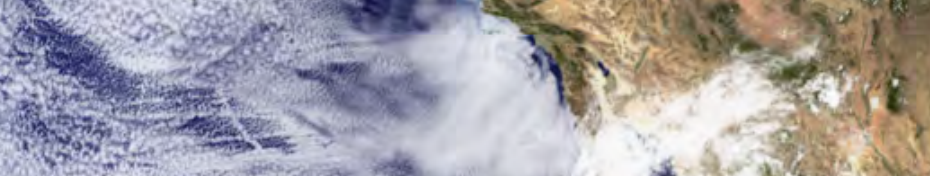

mat

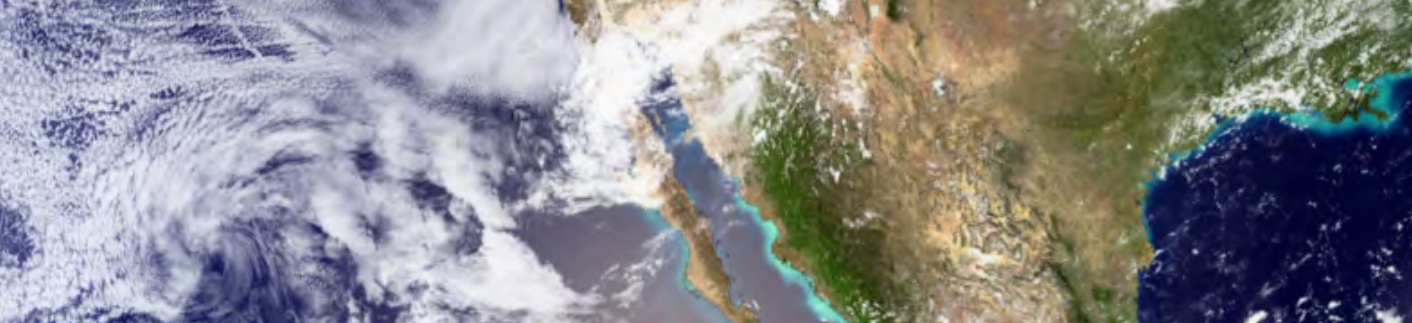

(1.4)

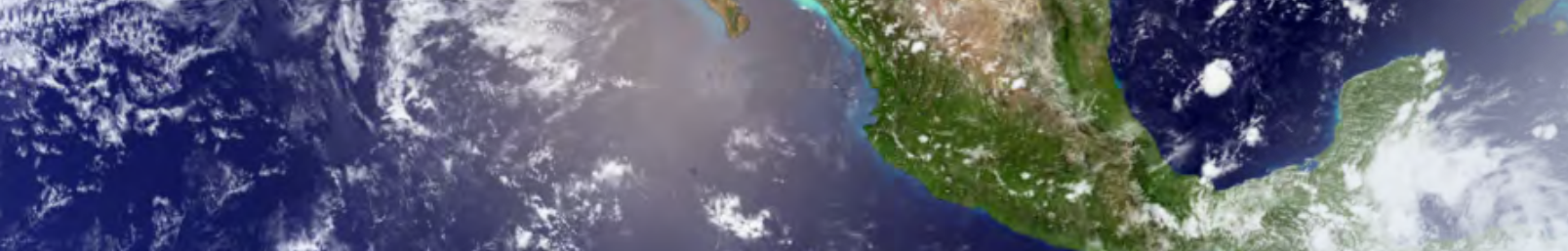

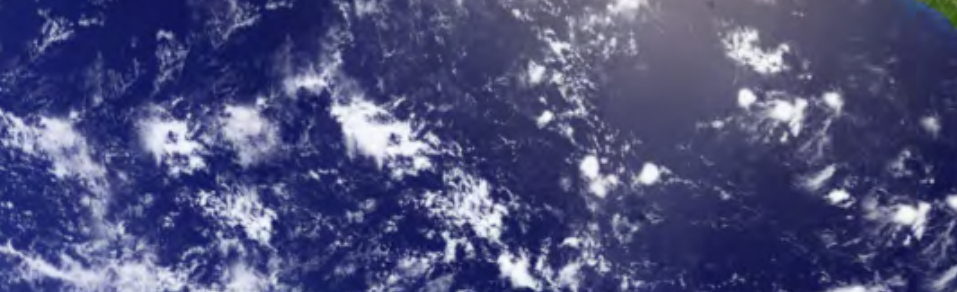

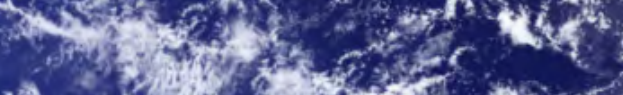

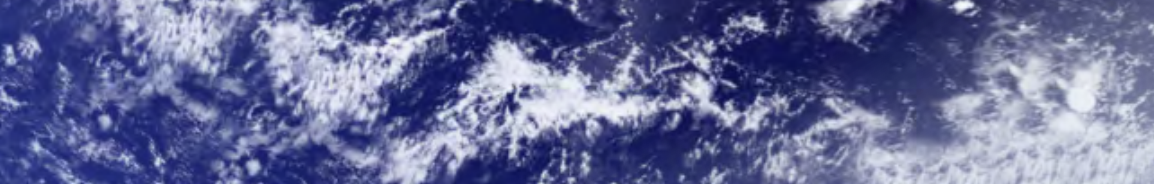

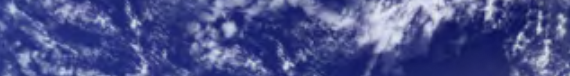

H.t.

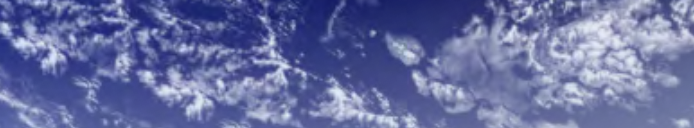

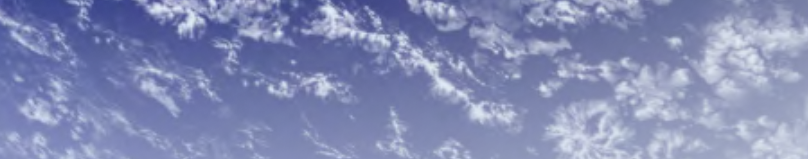

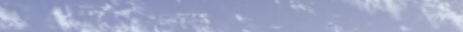




\title{
U.S. Geological Survey Fundamental Science Practices
}

\author{
By the Fundamental Science Practices Advisory Committee
}

\author{
No matter what policies and guidelines are developed, the responsibility \\ for science excellence remains where it has always been-in the hands \\ and minds of the dedicated scientists of the USGS. \\ -Charles G. Groat, 13th Director, USGS
}

\section{Background}

The U.S. Geological Survey (USGS) was established during the final session of the 45th Congress by the Organic Act of March 3, 1879 (20 Stat. 394; 43 U.S.C. 31). The USGS was placed in the Department of the Interior and was charged with a unique combination of responsibilities: "...classification of the public lands, and examination of the geological structure, mineral resources, and products of the national domain." The legislation stemmed from a report by the National Academy of Sciences, which in June 1878 had been asked by Congress to provide a plan for surveying the Territories of the United States that would secure the best possible results at the least possible cost. The necessity for communication of the best possible results led to the establishment of an ongoing tradition of internal and external publication of USGS information products and the longstanding USGS reputation for scientific excellence guided by the internal quality standards and processes applied when developing these products.

The USGS is an independent science agency that serves the Nation by providing reliable scientific information to describe and understand the Earth; minimize loss of life and property from natural disasters; manage water, biological, energy, and mineral resources; and enhance and protect our quality of life. With no regulatory or management mandate, the USGS is able to provide impartial science to address the needs of our changing world. A diversity of scientific expertise enables the USGS to carry out multiscale, multidisciplinary investigations that continue to add to the base of knowledge about the Earth. Through these efforts, the USGS provides citizens and decision makers at all levels of government with information needed to address critical societal issues. USGS Circular 1309, "Facing Tomorrow's Challenges-U.S. Geological Survey Science in the Decade 2007-2017" (http://pubs.usgs.gov/circ/2007/1309/) describes current Bureau science emphases, all of which are supported by USGS Fundamental Science Practices (FSP).
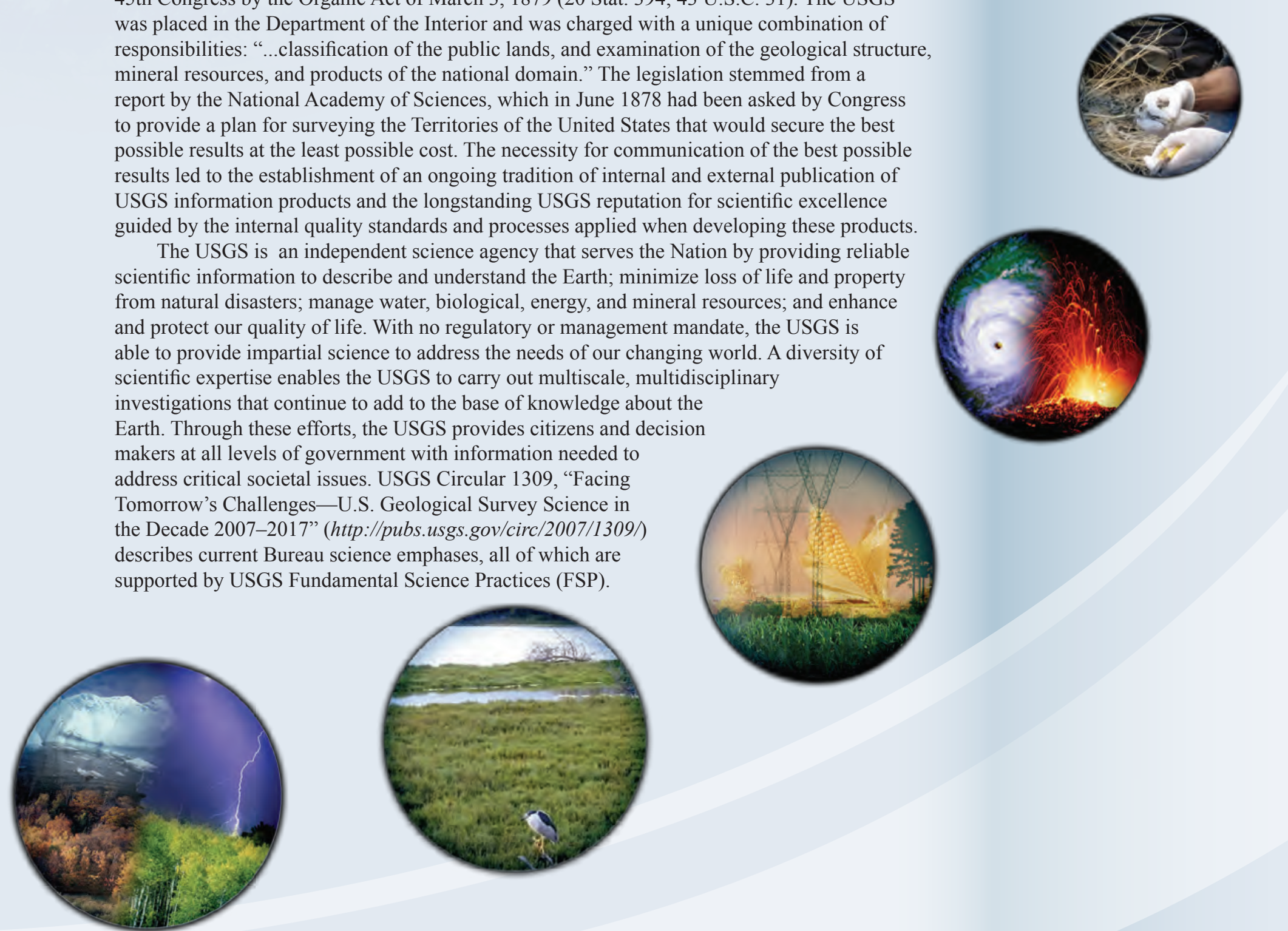


\section{Fundamental Science Practices}

The USGS has a long and proud tradition of objective, unbiased science in service to the Nation. A reputation for impartiality and excellence is one of our most important assets.

To help preserve this vital asset, in 2004 the Executive Leadership Team (ELT) of the USGS was charged by the Director to develop a set of fundamental science practices, philosophical premises, and operational principles as the foundation for all USGS research and monitoring activities.

In a concept document, "Fundamental Science Practices of the U.S. Geological Survey," the ELT proposed "a set of fundamental principles to underlie USGS science practices." The document noted that protecting the reputation of USGS science for quality and objectivity requires the following key elements:

- Clearly articulated, Bureau-wide fundamental science practices.

- A shared understanding at all levels of the organization that the health and future of the USGS depend on following these practices.

- The investment of budget, time, and people to ensure that the USGS reputation and high-quality standards are maintained.

FSP encompass all elements of research investigations, including data collection, experimentation, analysis, writing results, peer review, management review, and Bureau approval and publication of information products. The focus of FSP is on how science is carried out and how products are produced and disseminated. FSP is not designed to address the question of what work the USGS should do; that is addressed in

USGS science planning handbooks and other documents.

Building from longstanding existing USGS policies and the ELT concept document, in May 2006, FSP policies (refer to http://www.usgs.gov/fsp/ policies.asp) were developed with input from all parts of the organization and were subsequently incorporated into the Bureau's Survey Manual. In developing an implementation plan for FSP policy, the intent was to recognize and incorporate the best of USGS current practices to obtain the optimum overall program for our science. In January 2009, the USGS moved to full implementation of FSP. The FSP Advisory Committee (FSPAC) was formed to serve as the Bureau's working and standing committee to ensure the objectivity and quality of the Bureau's science information products and to provide support for the full implementation of FSP.

\section{FSP Web Sites}

The FSP Intranet site (http://internal.usgs.gov/fsp/ policies.html) serves as a resource for USGS employees, particularly USGS scientists, supervisors, managers, reviewers, approving officials, and publishing professionals. The Intranet site helps USGS employees find the information and guidance they need to ensure that we are continually maintaining the objectivity and quality of USGS science and how information products are developed, reviewed, approved, and released.

The FSP Internet site (http://www.usgs.gov/fsp/) is the primary resource for our stakeholders, partners, and the public to obtain information about FSP. The site provides users with quick and easy navigation to FSP policy and procedural and guidance materials.

\section{Roles and Responsibilities}

FSP are the collective and shared responsibility of everyone in the USGS. Designated officials and offices have specific roles, authorities, and functions in establishing the policies that underpin these practices:

- The Director of the USGS has final authority and responsibility for FSP and for the excellence, integrity, and objectivity of USGS science and of its information products.

- Associate Directors set policy for how scientific investigations, research, and activities are carried out and how information products are reviewed and approved for release and dissemination. They provide oversight for the processes and policies that govern FSP. They collaborate with Area Executives to address issues or take corrective action with regard to these policies.

\section{- The Office of Science Quality and Integrity} executes FSP policies, including the appointment of officials who approve information products for release (refer to http://www.usgs.gov/usgs-manual/200/205-18. html). This Office collaborates with Associate Directors and Area Executives to address issues or take corrective action regarding the execution of these policies and maintains the policy documents and procedures that pertain to FSP. 
USGS information products that are reviewed and approved in accordance with FSP policies follow a standard workflow (p. 4-5) that includes other specific roles and responsibilities as follows:

- Science Center Managers or their equivalents ensure that standards for scientific quality are met; that is, methodology is documented, and accepted metadata standards are used. They determine if a planned product qualifies as influential scientific information or highly influential scientific assessment (as defined in the Office of Management and Budget (OMB) directive available at $h t t p: / / w w w . u s g s . g o v /$ peer_review/) and therefore must adhere to the OMB requirements for peer review of influential products. They ensure that only properly peer reviewed products are forwarded to Bureau Approving Officials (for products that contain new interpretive information) and alert these officials about potential high-visibility products or policy-sensitive issues. They have delegated authority for Bureau Approval of information products that do not contain new interpretive information, all abstracts (except extended abstracts), and all poster and presentation materials disseminated to the public or left with the meeting sponsor. They also ensure that information products conform to USGS publishing requirements (refer to SM Part 1100, Publishing at http://www.usgs.gov/usgsmanual/t500.html\#pubs) and that official records are archived at their centers or placed in 


\section{U.S. Geological Survey Fundamental Science Practices (FSP) Information Product Workflow}

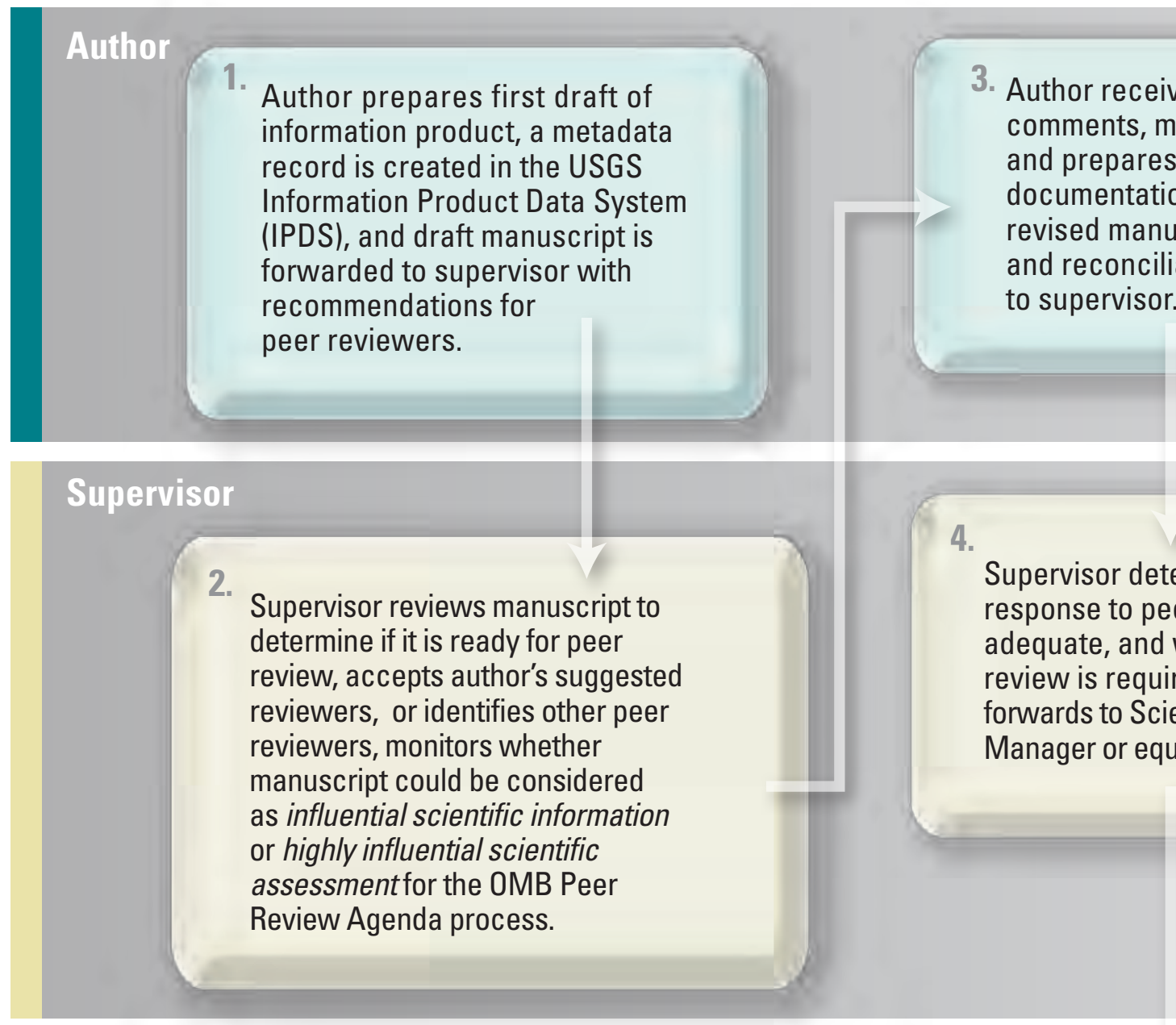

\section{Science Center Manager}

5.

SC Manager or equivalent reviews all documentation and, if appropriate, forwards package to Bureau Approving Official (BAO) for approval.

\section{Bureau Approving Official}

6.

$\mathrm{BAO}$ ensures all required reviews are performed, validates peer review reconciliation, identifies any revisions needed, and returns (for additional review or revision) approved or unapproved package to SC Manager or equivalent. 
8. Author responds to revisions recommended and (or) required by $\mathrm{BAO}$.
9. Approved manuscript is submitted for internal release (USGS Series) or for external publication and citation, and related metadata are entered into IPDS by author or alternate.

\section{SC Manager or equivalent} sends package to author for appropriate action. 
ideas by one or more scientists (peers) who are sufficiently well qualified, who are without conflict of interest, and who are not associated with the work being performed. A peer is defined as one who is of equal standing with another; in science, the implication is that education and (or) experience qualify one to comment on the work of others in a particular field of expertise. Peer reviewers may be internal or external to the USGS.

Peer review is required for all information products, regardless of media (print, digital, audiovisual, or Web),

- whether published and disseminated by the USGS or by an outside entity,

- whether the work was funded in whole or in part by the USGS,

- and as long as USGS affiliation is identified with authorship (refer to http://www.usgs.gov/usgsmanual/500/502-3.html).

In keeping with practices in the broader scientific community, directives from Government authorities, and FSP, the following, in part, is USGS peer review policy:

- Peer reviews must include at least two qualified scientists who have no stake in the outcome of the review, who are not associated with the work being performed, and who are without conflict of interest.

- Only peer-reviewed information products may be forwarded to an Approving Official for Bureau Approval. Information products sent to an Approving Official must include reconciliation documentation indicating how review comments were addressed.

\section{Federal Peer Review Requirements}

The OMB directive, Final Information Quality Bulletin for Peer Review, dated December 16, 2004, requires that there be a "systematic process of peer review planning" and access to a list of information products for official dissemination that will be peer reviewed as either influential scientific information or highly influential scientific assessments (as defined in the OMB directive). The OMB requirements do not replace or duplicate the USGS peer review requirements. The USGS has the responsibility to maintain and conduct the appropriate peer review process for its products and to identify products as influential according to the OMB definitions.

A list of USGS information products peer reviewed as influential scientific information or highly influential scientific assessments can be found at http://www.usgs.gov/ peer_review/.

\section{The Bureau Approval Process}

All information products must receive review and approval by line supervisors of the senior USGS author before subsequently receiving final Bureau Approval. Bureau Approval validates the scientific excellence of the information product and includes a policy review to ensure that all policy requirements relevant to FSP are met and to identify policysensitive issues including those that may have implications related to current policy or that may involve matters of national interest, security, or potential commercial gain. Bureau Approval also ensures that all appropriate reviews, such as peer review, have been conducted. Review of products for Bureau Approval addresses criteria such as integrity and objectivity, conflict of interest, impartiality and nonadvocacy, methodology and documentation, public benefit and access, natural hazards, and (or) public or wildlife health. Delegations of authority to officials who grant Bureau Approval are detailed in the Survey Manual (http://www.usgs.gov/usgsmanual/200/205-18.html).

\section{Scientific Integrity}

In January 2007, USGS released a policy on scientific integrity (refer to http://www.usgs.gov/usgsmanual $/ 500 / 500-25 . h t m l)$ that describes our requirements "for ensuring scientific integrity in the conduct of scientific activities and procedures for reporting, investigating, and adjudicating allegations of scientific misconduct by USGS employees and volunteers." The policy contains a "code of scientific conduct" that not only documents research standards but also assures customers, partners, and the general public that USGS abides by them in all aspects of scientific work performed. A USGS Scientific Misconduct/Integrity Review Panel has also been in place since 2007.

\section{Functions Supporting FSP}

\section{Science Publishing Network}

Building upon its reputation for publishing excellence, the USGS implemented a Bureau-wide publishing approach through the Science Publishing Network (SPN) that directly supports all employees of the USGS as well as the many partners, suppliers, and consumers of 
USGS data and information products and services. Production support is coordinated at Publishing Service Centers located across the Nation, thus ensuring workload balancing and optimizing network efficiencies throughout the Bureau. SPN services include technical and scientific editing, graphics support, publication layout and design, Web and print release of all USGS series publications, and customized support for other USGS products including abstracts, posters, journal articles, books, presentation materials, Web pages, internal documents, and outreach materials. Additional information on USGS publishing is available at http://www.usgs.gov/publishing/.

\section{Information Product Data System}

The standard workflow steps for products that are reviewed and approved in accordance with FSP requirements (p. 4-5) have been incorporated into IPDS, the Bureau's official tracking system for managing the development steps of USGS information products that require Bureau Approval. IPDS workflows track and document the review and approval process as it occurs. The resulting IPDS workflow history provides documentation to show that proper procedures have been followed and that the necessary steps have been taken. IPDS also manages the documents that support the review and approval process. Peer review comments, author peer review reconciliation documents, and other archival records that are stored in IPDS provide documentation of compliance with FSP and, in accordance with USGS requirements ( $h t t p: / / w w w$. usgs.gov/usgs-manual/schedule/432-1-s1/index1.html) and the National Archives and Records Administration, satisfy requirements for storing these documents. IPDS is used to document and certify that Bureau Approval has been granted.

\section{For More Information}

The primary sources of FSP information for USGS employees are their immediate supervisors, Science Center Managers, Bureau Approving Officials, and the internal FSP Web site. Additionally, USGS employees, as well as all other parties, should contact the FSPAC (by email at gs_fspac@ usgs.gov) for FSP-related questions and concerns or visit the public FSP Web site at http://www.usgs.gov/fsp/. 
